\title{
Management of Large-Scale Transformation Programs: State of the Practice and Future Potential
}

\author{
Gerrit Lahrmann ${ }^{1}$, Nils Labusch ${ }^{1}$, Robert Winter ${ }^{1}$, Axel Uhl ${ }^{2}$ \\ ${ }^{1}$ Institute of Information Management, University of St.Gallen, \\ St.Gallen, Switzerland \\ \{Gerrit.Lahrmann, Nils.Labusch, Robert.Winter\}@unisg.ch \\ ${ }^{2}$ University of Applied Sciences and Arts Northwestern Switzerland FHNW, SAP AG, \\ Basel, Switzerland \\ Axel. Uhlefhnw.ch
}

\begin{abstract}
In addition to continuous, evolutionary optimizations, most enterprises also undergo revolutionary transformations from time to time. Knowledge about current corporate practice for coherent IT and business transformation is therefore very valuable. In this paper we present the results of an empirical study on the management of large-scale transformation programs that focuses on IT as much as business aspects. Companies that rate themselves as mature with regards to transformation management, assess certain transformation management components different than less mature companies. Cost reduction, revenue improvement, and agility improvement are the most relevant goals of transformation programs - all these are business goals and not IT goals. Current state of the practice transformation management can be classified into three approaches: Value-driven, ungoverned and change-driven. We found that no single management approach covers all these areas appropriately yet.
\end{abstract}

Keywords: transformation methodology, empirical study, holistic transformation management

\section{Introduction}

According to Rouse [1], transformation and especially enterprise transformation (ET) is not routine but "fundamental change that substantially alters an organization's relationships with one or more key constituencies, e.g., customers, employees, suppliers, and investors". Such an ET can involve new value propositions or change the inner structure of the enterprise. Further, ET could involve old value propositions provided in fundamentally new ways [1]. Reasons can be the reaction to an insecure, permanently changing economic environment [2] or the pro-active measure to explore business potentials, e.g. those of IT innovations [3]. Further examples are mergers \& acquisitions, detachment of host systems or other efforts that are reflected in strategic 
planning. ETs are usually implemented as programs, i.e. bundles of projects [4], while evolutionary changes are either implemented by regular projects or are even included in permanent processes.

Due to the complex intertwining of IT and business in many companies [5], one challenge of ET programs is to address the often diverse worlds of business and IT coherently [6]. Examples from our survey are the introduction of a new banking platform for all units of a banking group (program duration two years, program budget 60 million Euros, 120 full time employees on average) or the world-wide standardization of business processes on the basis of a unified enterprise resource planning platform in a high tech company (program duration four years, program budget considerably more than one billion Dollars).

Thus, in the following sections we present the results of an empirical study on the management of large-scale ET programs and extend a study that was partially reported in [7]. In the paper at hand we present more details, e.g. qualitative statements concerning the experiences within the described ETs. We further provide a more detailed discussion and analysis of results and implications for corporate practice. First, we are interested in the current practice of ET programs, their extent as much as the guiding goals and key drivers. We reflect this interest in our first research question:

\section{RQ1: What is the current corporate practice of enterprise transformation?}

Managing and conducting ET is a complex issue [8]. Since many ETs fail [9], we are particularly interested in success factors for effective ET. Motivated by Robbins [10], we especially consider a holistic approach as being appropriate. We cover this aspect with our second research question:

RQ2: What are success factors for effective enterprise transformation, especially within a holistic enterprise transformation management approach?

For the successful management of ETs, many different tasks and techniques need to be executed and coordinated [11]. In the next part of our study, we aim at getting an overview of currently executed tasks and techniques concerning ET. Further we are interested in the combinations mostly present, in order to reflect these with the success factors. This leads to the third research question:

\section{RQ3: What are prevalent approaches to conduct enterprise transformation management?}

Connected to these research questions, the subject occurs, which areas of ET management offer potentials for further research and practice design solutions. Therefore, we are interested in gaps of current ET approaches and in the maturity of its components (techniques). We address the matter with a last research question: 


\section{Management of Large-Scale Transformation Programs: State of the Practice and Future}

Potential 3

RQ4: Which components of enterprise transformation management offer the largest improvement potential?

The remainder of the paper is structured as follows. First, we give a brief introduction to ET management. Next, we outline our research approach. Then we present the results of our study. We conclude with a discussion of our results, limitations and an outlook on future work.

\section{Enterprise Transformation Management}

As a formal construct, ET can be understood as a process or a sequence of activities that change an organization in its present or initial state to a future, desirable target state. Therefore, ET becomes a plan of how a firm intends to move from one position to another [6]. According to Baumoel [12], change or ET programs are unique, because they are embedded into unique contexts, i.e. the economic, technological, and social environment. As a consequence, the setup and the execution of ET programs need to refer to this unique context [12] (see figure 1).

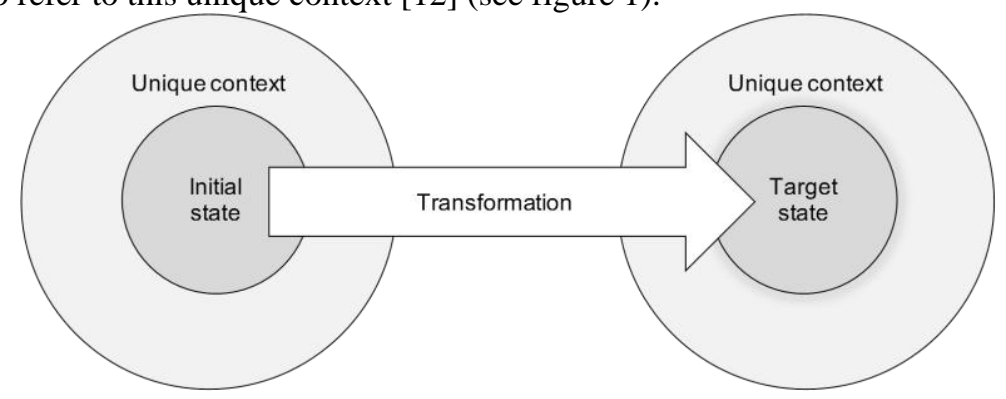

Fig. 1. Conceptual model of transformation [13]

ETs usually are comprised of technological and social components [6]. Technologies, or more specifically IT, can be both enabler and driver of ETs. Examples are knowledge management or collaboration technology [6]. The social components of ET induce certain irrationality during ET endeavors. This implies that technological and work-processes need to be developed jointly during ETs [6]. How and when ETs are conducted is mostly induced by the market environment [14] - companies conduct ET decisions in response to the situations in which they find themselves. According to $\mathrm{Yu}$ et al. [14] "companies will transform their enterprise by some combination of predicting better, learning faster, and acting faster, as long as the market is sufficiently predictable to reasonably expect that ET will improve the market value the company can provide".

In order to foster successful ET and to improve the gained value, a precondition is having an understanding of how to systematically manage ET programs. We understand "enterprise transformation management" as the process of goal-directed planning, implementation, and control of fundamental changes in companies. In response to the limitations of single methods and management approaches and in 
view of the complexity of ETs, ET management integrates and extends existing management approaches like strategic management, value management, risk management, project management, (business) process management, change management, competence management, and of course IT transformation management. An example for such an approach is Business Transformation Management Methodology $\left(\mathrm{BTM}^{2}\right)$ [15]. It is comprised of an overarching discipline called meta management that offers a cyclic and iterative phase model for ETs (envision, engage, transform and optimize), a structure including roles and disciplinary ET activities, provision of measures, skill development support and guiding principles.

At this point, there is no related work that provides an overview about current management practice of large scale ET programs. In order to document current ET management practice, to analyze improvement potentials and to close this gap, we conducted the empirical study at hand.

\section{$3 \quad$ Research Methodology}

\subsection{Study Concept}

We conducted the empirical study by means of a written questionnaire. For the design of the questionnaire, we basically adhered to the process as proposed by [16]. First, we compiled question groups for each topic of interest. Second, we identified poorly or ambiguous worded items and made minor wording changes until consensus was found and no further problems were uncovered. The remaining items were included in the survey instrument, most of them measured on a 5-point Likert scale [17]. However, in order to gain further insights, we added open questions to the questionnaire in order to have the chance for further in-depth insights [18]. Before being distributed, the questionnaire instrument was pre-tested as a whole by two participants. The final survey consisted of five parts. In part I, demographic information on the study participants, their company, and, in part II, their company's ET program was acquired. In part III, a literature-based [3, 12, 19, 20, 21] holistic ET management approach was presented to the participants, whose potential the participants were asked to assess. In part IV, the study participants were asked, how mature they would estimate their own company as regards certain components of the holistic ET management approach and as how important they would rate each component. Further questions were used to assure the completeness of the approach. In part V, further ET management aspects, e. g. enablers and inhibitors, were documented.

\subsection{Data Collection}

We targeted heads of current ET programs in large, multi-national companies (program managers, head of ET competency centers, regional CIOs, etc.). We consider a rather low amount of high knowledgeable informants to be more appropriate than a high amount of less knowledgeable but better accessible ones. Only 


\section{Management of Large-Scale Transformation Programs: State of the Practice and Future}

Potential 5

high knowledgeable informants are able to view the focal phenomena from diverse perspectives [22]. We selected our informants by two major criteria: First, they needed to be located in management or positions closely related to management. Second, they needed to have major influences and insights into the ET program. We identified the informants by having access to the customer network of a large consulting company and the university network. We further applied snowball sampling techniques in order to increase the amount of informants [23]. We contacted the informants by providing a brief management summary of the study via mail or email. We further attached the questionnaire and asked participants to send it back via mail or fax. We provided the chance to include contact data in order to allow for the provision of study results when interested. However, in general, we gave anonymity to our informants in order to receive honest answers and reduce biases [18].

\subsection{Data Analysis}

Depending on the type of question in the questionnaire we applied different analysis techniques. For the closed questions, we applied quantitative analysis techniques in an exploratory manner [18]. We used factor analyses in order "to summarize relationships in the form of a more parsimonious set of factor scores that can then be used in subsequent analyses" [24] and thus identify variables and questions that belong together. In order to further match cases in groups that belong together, we applied hierarchical clustering [25]. The purpose of clustering, a form of combinatorial data analysis, is to investigate "a set of objects in order to establish whether or not they fall $[\ldots]$ into groups $[\ldots]$ of objects with the property that objects in the same group are similar to one another and different from objects in other groups." [25]

Based on open questions, we asked for key deliverables, drivers, and inhibitors of successful ET programs. We analyzed the open questions in two different ways. First, in order to derive interpretable results, a standardized process for content analysis (conceptualization, codebook creation, coding, refinement, \& reliability check) was applied, thereby helping to ensure the necessary rigor in the classification process [26]. First, we matched synonyms. As an example, one participant used the term "New optimized way of doing business" and another participant used the term "Process improvements", both actually addressing a similar aspect. The outcomes are three lists of key deliverables, drivers, and inhibitors of ET programs, which should cover all aspects as mentioned by the study participants. Second, we extracted interesting arguments in a qualitative manner [18] and present those within the results section.

\subsection{Data Set}

Both business and IT representatives participated. The study was conducted globally, certainly with a focus on Europe (Europe 68\%, Americas 14\%, Asia 14\% and Africa $4 \%$ ). Altogether, 28 companies (respectively their representatives) participated. In the data set, the primarily present industries were high tech (25\%), consumer products 
(14\%), banking and insurance (7\%), and professional services $(7 \%)$. Our rather elusive focus on heads of large-scale ET management programs explains the rather low number of participating organizations. However, we consider this as appropriate, since the scope of the paper at hand is rather explorative and less confirmative. Table 1 summarizes the most important measures of the data set.

Table 1. Characterization of the data set

\begin{tabular}{llllll}
\hline Function & \multicolumn{3}{l}{ Industry } & \multicolumn{2}{l}{ Region } \\
\hline C-Level Executive & $11 \%$ & High Tech & $25 \%$ & Europe & $68 \%$ \\
\hline Director / Head of ... & $32 \%$ & Consumer Products & $14 \%$ & Americas & $14 \%$ \\
\hline (Program) Manager & $25 \%$ & $\begin{array}{l}\text { Banking and } \\
\text { Insurance }\end{array}$ & $7 \%$ & Asia & $14 \%$ \\
\hline Business or IT Architect & $14 \%$ & Professional Services & $7 \%$ & Africa & $\%$ \\
\hline Other & $18 \%$ & Other & $46 \%$ & & \\
\hline Division & & Company Size & & & \\
\hline Business & $29 \%$ & $1-999$ & $18 \%$ & & \\
\hline IT & $61 \%$ & $1000-9999$ & $11 \%$ & & \\
\hline Business / IT & $11 \%$ & 10000 and above & $71 \%$ & & \\
\hline
\end{tabular}

\section{Study Results}

\subsection{Enterprise Transformation in Current Corporate Practice}

Foremost, the ET programs we investigated in the study had a program duration between two and four years and a program budget between ten and 100 million Euros. In smaller companies $\left(<10^{\prime} 000\right.$ employees), 52 full time employees (FTEs) were working on average on the ET program. In larger companies ( $>10^{\prime} 000$ employees), this number went up to 126 FTEs. Most of the programs have a clear business focus or combine elements of business and IT transformation. Our results show that cost reduction, revenue improvement, and agility improvement are the most relevant goals in ET programs. Agility improvement is the ability of being able to react fast to necessary changes. Business networking has not yet arrived. Despite the economic crisis, risk reduction still has a low priority. In table 2 the goals of ET programs are summarized. The list is sorted by relevance (= frequency of mention* priority). The list is based on and extends a classification by Baumoel [12]. 
Management of Large-Scale Transformation Programs: State of the Practice and Future

Table 2. Goals of ET programs

\begin{tabular}{llll}
\hline Goals & Frequency & $\begin{array}{l}\text { Average } \\
\text { Priority }\end{array}$ & Relevance \\
\hline Cost reduction & $82 \%$ & 4.22 & 3.46 \\
\hline Revenue improvement & $71 \%$ & 4.50 & 3.21 \\
\hline Agility improvement & $68 \%$ & 4.37 & 2.96 \\
\hline Strategy adaptation & $64 \%$ & 4.17 & 2.68 \\
\hline Process redesign & $64 \%$ & 3.78 & 2.43 \\
\hline Technology-enabled growth & $61 \%$ & 3.47 & 2.11 \\
\hline Risk reduction & $54 \%$ & 3.27 & 1.75 \\
\hline Business networking & $32 \%$ & 2.78 & 0.89 \\
\hline
\end{tabular}

As key deliverables, the study participants named business optimization, operating models, standardized processes \& platform as much as roadmaps. These are all business-driven topics. Drivers of successful ET programs are top management support, stakeholder management, and clear responsibilities. Resistance to change, organizational barriers, and resource constraints are inhibitors of successful ET. Table 3 summarizes the key deliverables, drivers, and inhibitors of successful ET programs.

Table 3. Top key deliverables, drivers, and inhibitors of ET programs

\begin{tabular}{llll}
\hline Rank & Key Deliverables & Drivers & Inhibitors \\
\hline 1 & Business optimization & Top management support & Resistance to change \\
\hline 2 & Operating model & Stakeholder management & $\begin{array}{l}\text { Organizational } \\
\text { barriers }\end{array}$ \\
\hline 3 & $\begin{array}{l}\text { Standardized processes } \\
\text { \& platform }\end{array}$ & Clear responsibilities & Resource constraints \\
\hline 4 & Roadmap & $-/-$ & $-/-$ \\
\hline
\end{tabular}

\subsection{Success Factors of Enterprise Transformation Management}

In order to be more effective, ET management requires a comprehensive overall view of the construction and changing of an organization's structures, i.e. its organizational design [10]. As a basis for this, adequate interdisciplinary approaches should be used, which do not only concentrate on one aspect of the ET process, e.g. the role of IT, but rather include the main levers of organizational ET from all relevant disciplines (e. $g$. strategy making, organizational design and behavior, or business process engineering) [12].

Therefore, in order to analyze such an interdisciplinary approach and to get a more or less complete overview of ET management, we derived components of a holistic 
ET management approach from the literature. Based on the established Business Engineering framework [3], the approach presented in table 4 is structured into the three layers Strategy, Processes \& Organization as much as Information Systems \& Technology. Altogether, the holistic ET management approach contains 13 subparts or ET management components (see table 4).

Table 4. Holistic ET management

\begin{tabular}{|c|c|c|c|}
\hline $\begin{array}{l}\text { Holistic Enterprise Transformation } \\
\text { Management }\end{array}$ & $\begin{array}{l}\text { Importance } \\
\text { in mature } \\
\text { companies }\end{array}$ & $\begin{array}{l}\text { Importance in } \\
\text { less mature } \\
\text { companies }\end{array}$ & Difference \\
\hline Strategy & 4.33 & 3.80 & $\mathbf{0 . 5 3}$ \\
\hline $\begin{array}{l}\text { A joint (company and implementation } \\
\text { partner) agreement on business objectives }\end{array}$ & 4.78 & 3.44 & 1.33 \\
\hline $\begin{array}{l}\text { Mid-term planning and continuous alignment } \\
\text { of business requirements and IT capabilities }\end{array}$ & 3.78 & 4.00 & -0.22 \\
\hline Management of program value & 4.38 & 3.56 & 0.81 \\
\hline $\begin{array}{l}\text { Identifying and managing interdependencies } \\
\text { of projects within and across programs }\end{array}$ & 4.40 & 4.20 & 0.20 \\
\hline Processes and Organization & 4.21 & 3.51 & 0.70 \\
\hline $\begin{array}{l}\text { Business process optimization and innovation } \\
\text { services }\end{array}$ & 4.29 & 3.73 & 0.56 \\
\hline $\begin{array}{l}\text { A joint (company and implementation } \\
\text { partner) governance model }\end{array}$ & 4.23 & 3.57 & 0.66 \\
\hline Organizational change management & 4.33 & 3.71 & 0.62 \\
\hline $\begin{array}{l}\text { High qualified representative of } \\
\text { implementation partner }\end{array}$ & 4.13 & 3.56 & 0.57 \\
\hline $\begin{array}{l}\text { Professional program and project } \\
\text { management }\end{array}$ & 4.08 & 3.00 & 1.08 \\
\hline Information Systems \& Technology & 3.53 & 3.26 & 0.27 \\
\hline $\begin{array}{l}\text { Tool-supported transparency on progress, } \\
\text { risks, and costs of ET program activities }\end{array}$ & 3.89 & 3.13 & 0.76 \\
\hline IT architecture services & 3.30 & 3.44 & -0.14 \\
\hline $\begin{array}{l}\text { High qualified IT people with excellent } \\
\text { business understanding }\end{array}$ & 3.82 & 3.75 & 0.07 \\
\hline Monitoring of technology trends & 3.10 & 2.71 & 0.39 \\
\hline
\end{tabular}

In order to analyze if ET programs are more successful if a holistic ET management approach is used, we asked for the company representatives' estimation as regards impact on ET program execution. The study participants could chose if they wanted to estimate the impact on the basis of their own companies' ET program or an 
exemplary ET program. Table 5 summarizes the estimation of the company representatives as regards impact on program quality, program budget, program duration, and program risk. Program quality describes that all goals were achieved and that the ET is sustainable.

Table 5. Impact on ET programs

\begin{tabular}{lll}
\hline $\begin{array}{l}\text { Impact on Enterprise } \\
\text { Transformation Program Execution }\end{array}$ & Positive Impact & Negative Impact \\
\hline Program quality & $100 \%$ & $0 \%$ \\
\hline Program budget & $76 \%$ & $24 \%$ \\
\hline Program duration & $75 \%$ & $25 \%$ \\
\hline Program risk & $92 \%$ & $8 \%$ \\
\hline
\end{tabular}

Altogether, all participants expect a better program quality. More than three quarters of the participants expect that the extra costs of the components will be compensated by better quality. Only one quarter expects higher quality along with higher program budgets and higher program duration. As regards program risk, expectations of a positive impact prevail.

\subsection{Approaches of Enterprise Transformation Management}

In order to identify archetypal ET management approaches which are currently used in corporate practice, we conducted an exploratory analysis [27]. In order to elucidate the predominant design factors of ET management approaches, data is examined by factor analysis. The five factors consist of two to four items. Items are usually assigned to a factor if the factor loading adds up to at least 0.5 [27]. In the cases of "Mid-term planning and continuous alignment" and "Professional program and project management", the items are attributed to the factor with the highest factor loading. Based on an interpretation of the contained items, we termed the five design factors of ET management approaches as "People \& Technology Governance", "Holistic Change Management", "Target-Driven Planning", "Commitment to Transformation", and "Benefits Management". See table 6 for the detailed loadings and factor items. 
Table 6. Results of the Factor Analysis

\begin{tabular}{|c|c|c|c|c|c|c|}
\hline Factors & Item description & $\mathrm{F} 1$ & $\mathrm{~F} 2$ & $\mathrm{~F} 3$ & $\mathrm{~F} 4$ & F5 \\
\hline \multirow{3}{*}{$\begin{array}{l}\text { People \& } \\
\text { Technology } \\
\text { Governance }\end{array}$} & $\begin{array}{l}\text { High qualified IT people with } \\
\text { excellent business understanding }\end{array}$ & 0.93 & 0.09 & 0.14 & -0.02 & 0.16 \\
\hline & Monitoring of technology trends & 0.81 & -0.06 & 0.04 & 0.37 & 0.24 \\
\hline & $\begin{array}{l}\text { Joint (company and implementation } \\
\text { partner) governance model }\end{array}$ & 0.51 & 0.46 & 0.44 & 0.25 & 0.01 \\
\hline \multirow{2}{*}{$\begin{array}{l}\text { Holistic } \\
\text { Change } \\
\text { Management }\end{array}$} & $\begin{array}{l}\text { Identifying and managing } \\
\text { interdependencies of projects }\end{array}$ & -0.07 & 0.86 & -0.01 & 0.07 & 0.18 \\
\hline & Organizational change management & 0.10 & 0.76 & 0.23 & 0.27 & -0.08 \\
\hline \multirow[t]{4}{*}{$\begin{array}{l}\text { Target-driven } \\
\text { Planning }\end{array}$} & $\begin{array}{l}\text { Joint (company and implementation } \\
\text { partner) agreement on business } \\
\text { objectives }\end{array}$ & -0.08 & 0.28 & 0.79 & 0.11 & 0.31 \\
\hline & IT architecture services & 0.45 & -0.11 & 0.72 & 0.31 & 0.03 \\
\hline & $\begin{array}{l}\text { Mid-term planning and continuous } \\
\text { alignment }\end{array}$ & 0.29 & 0.18 & 0.56 & 0.21 & 0.53 \\
\hline & $\begin{array}{l}\text { Professional program and project } \\
\text { management }\end{array}$ & 0.40 & 0.43 & 0.45 & -0.36 & 0.20 \\
\hline \multirow[t]{2}{*}{$\begin{array}{l}\text { Commitment to } \\
\text { Transformation }\end{array}$} & $\begin{array}{l}\text { Business process optimization and } \\
\text { innovation services }\end{array}$ & 0.10 & 0.12 & 0.10 & 0.81 & -0.03 \\
\hline & $\begin{array}{l}\text { High qualified representative of } \\
\text { implementation partner }\end{array}$ & 0.17 & 0.28 & 0.23 & 0.69 & 0.24 \\
\hline \multirow[t]{2}{*}{$\begin{array}{l}\text { Benefits } \\
\text { Management }\end{array}$} & $\begin{array}{l}\text { Transparency on progress, risks, and } \\
\text { costs of ET program activities }\end{array}$ & 0.41 & -0.17 & 0.30 & -0.18 & 0.74 \\
\hline & Management of program value & 0.10 & 0.44 & 0.12 & 0.38 & 0.70 \\
\hline
\end{tabular}

Based on the factor scores of the factor analysis, hierarchical clustering is used, in order to determine archetypal ET management approaches. Altogether, we identified three different ET management approaches. Due to their characterizing factor scores, we termed these approaches as "Value-Driven Approach", "Un-Governed Approach", and "Change-Driven Approach" See table 7 for the clusters and the corresponding factor values. 
Table 7. Impact on ET programs

\begin{tabular}{lllllll}
\hline Cluster & $\mathrm{n}$ & $\begin{array}{l}\text { People \& } \\
\text { Technology } \\
\text { Governance }\end{array}$ & $\begin{array}{l}\text { Holistic } \\
\text { Change } \\
\text { Manage- } \\
\text { ment }\end{array}$ & $\begin{array}{l}\text { Target- } \\
\text { driven } \\
\text { Planning }\end{array}$ & $\begin{array}{l}\text { Commit- } \\
\text { ment to } \\
\text { Trans- } \\
\text { formation }\end{array}$ & $\begin{array}{l}\text { Benefits } \\
\text { Management }\end{array}$ \\
\hline 1 & 16 & $-0.47 \bigcirc$ & $-0.33 \bigcirc$ & $0.03 \bigcirc$ & $-0.18 \bigcirc$ & $-0.09 \bigcirc$ \\
\hline 2 & 7 & $-1.21 \bigcirc$ & $-0.34 \bigcirc$ & $-0.77 \bigcirc$ & $0.09 \bigcirc$ & $-0.21 \bigcirc$ \\
\hline 3 & 5 & $1.14 \bigcirc$ & $0.86 \bigcirc$ & $-0.70 \bigcirc$ & $0.60 \bigcirc$ & $-0.55 \bigcirc$ \\
\hline
\end{tabular}

Cluster one, that we call the Value-Driven Approach is present in $57 \%$ of the examined companies and can be characterized by a high Target-Driven Planning and a high Benefits Management. The average maturity of companies using the ValueDriven ET management approach is 3.30.

Cluster two, the Un-Governed Approach is present in almost $25 \%$ of the companies that have an average maturity level of 2.30. Especially a low people and technology governance can be seen in these companies.

Cluster three, the Change Driven Approach is present in $18 \%$ of the companies that have an average maturity of 3.43. In this cluster we can observe a high presence of people and technology governance, holistic change management and commitment to transformation.

All three approaches have in common that they place emphasis on different aspects, e. g. business value in the case of the Value-Driven Approach, but overall, a well-balanced, holistic approach is missing. Considering the potential of a holistic ET management approach, this opens room for improvement. The components which have been rated important by mature companies might be reasonable starting points for this.

\subsection{Potentials for Enterprise Transformation Support Improvement}

In our analysis, we asked for the maturity of companies as regards with regard to each ET management component as well as the importance attributed to each component. On a 5-point Likert scale, the company representatives were asked to estimate the maturity of their own company and the importance which is attributed to a component in their company (self-assessment). By partitioning the data set into mature (selfassessed values of four or five) and less mature (self-assessed values of one, two, or three) companies it is possible to highlight components which are critical for successful ET management. Furthermore, this analysis allows deriving development directions for single companies.

Companies, that attributed themselves to be mature, rated especially the following aspects as more important than less mature companies: Active management of ET in general (as mature companies rated almost all components to be more important than less mature companies), Operational and organizational structure in general (e. g. 
through a joint governance model and organizational change management) and certain strategic aspects (for example a joint agreement on business objectives).

The components which were rated with the highest importance and the lowest maturity at the same time offer the highest potential for improvement. Such components should be of particular interest for researchers as well as practitioners (see fig 2).

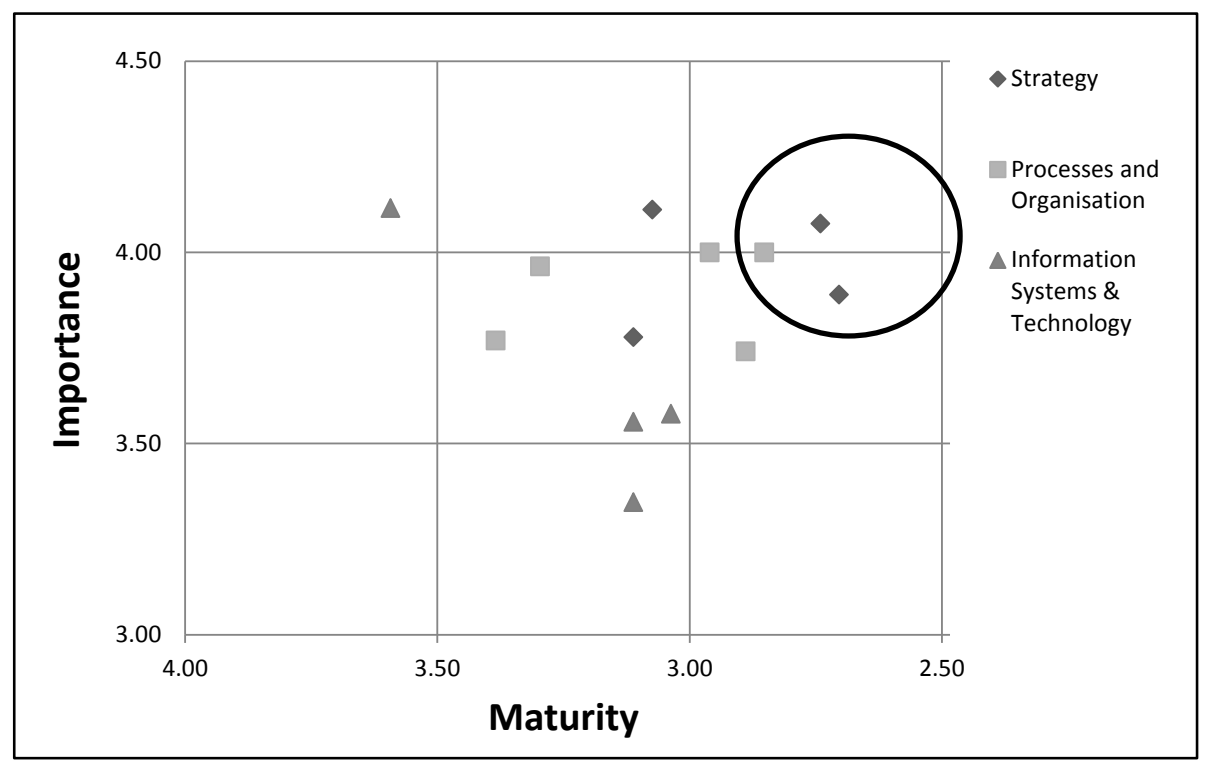

Fig. 2. ET management components with a high improvement potential

Based on this classification, the most important ET management components with the highest need for action are (illustrated by the black circle): "Identifying and managing interdependencies of projects within and across programs", "Management of program value" and "Business process optimization and innovation services".

\section{$5 \quad$ Discussion \& Outlook}

The results provide an explorative overview of ET programs currently conducted in corporate practice. Some further interesting hints about the future development of ET management approaches can be gained from direct statements the informants wrote in the questionnaires. We asked to openly provide major flaws and lessons learned from their point of view. One point that was mentioned by almost all informants is the importance of management support. Such support can be present to a different extent. While some mentioned management support in general, some directly referred to the board. However, a first challenge is to align within the Board. Like one informant stated as a critical point: 


\section{Management of Large-Scale Transformation Programs: State of the Practice and Future}

Potential

"Cross board area transformation goals were not defined and not aligned"

Therefore, in order to provide support as a board, first internal, cross-responsibility alignment needs to be achieved. After such alignment has been achieved, topmanagement support can be communicated credibly to the involved employees.

Further important are cultural aspects. Like one informant mentioned, knowledge, experience and courage concerning the relational aspects are very important. An example would be new ways of conducting work. Another informant mentioned, that the whole culture during an ET needs to shift away from a "it's their fault" towards a "we are all responsible and need to be a role-model". A third informant provided an interesting catch phrase for the importance of culture:

"Culture eats strategy for breakfast"

Another often mentioned aspect is communication. Many informants claim that communicating information to the people involved or affected by the ET is crucial to ensure its success. Like one informant claimed:

\section{"Communicate, Communicate, Communicate"}

However, such claim might go not fully cover the communication aspect since another informant claimed:

"Intense communication can result in information overload"

Therefore, communication during an ET is a matter that needs to be planned intensively and conducted in a meaningful but controlled fashion.

Our results and the statements above show that management of ET programs is an important topic - especially in large organizations. Currently, different approaches to ET management exist in corporate practice, but a holistic approach is not there yet. Nonetheless, all study participants attribute a high potential to such an approach: All participants agree that a holistic ET management approach will improve the quality of the ET and will thereby lead to a more sustainable goal achievement. Such an approach needs to be capable of aligning and coordinating the different stakeholders and disciplines that are involved in ETs. However, from our point of view such an approach also needs to be able to differentiate different situations in order to achieve a certain fit with the context at hand.

Some limitations occur in the design of the study at hand. The study targets at a high level of abstraction that needs to be detailed and developed towards a more operative solution in further research. The study cannot claim general and overall coverage, however, we claim that because of the high knowledgeable informants, relevant data could be collected and the study contributes to the body of ET knowledge. 
Concluding, the following points should be kept in mind in order to foster successful ET management:

First, Companies, that rate themselves as mature with regards to ET management, assess certain ET management components differently than less mature companies. Especially the active management of ET, the operational and organizational structures and certain strategic aspects receive higher attention in mature companies.

Second, Cost reduction, revenue improvement, and agility improvement are the most relevant goals of ET programs. It is worth to mention that these are all business and not IT-related goals. Information systems and supporting technology seem to be considered as a general precondition for successful ET management. Quite surprising in view of the recent financial and economic crisis is the fact that risk reduction has a low priority only.

Third, drivers and inhibitors of successful ET are dominated by soft factors. A key insight is that ET should be driven by business content and strategic aspects.

The findings of the study provide a foundation for further research in the field and the design of applicable artifacts like methods or reference frameworks. Based on the presented study, we plan to develop such artifacts especially in the areas identified in section 4.4. Identified gaps are "Identifying and managing interdependencies of projects within and across programs", "Management of program value" and "Business process optimization and innovation services". For the first identified gap, approaches like enterprise architecture can provide valuable support and should be researched and developed with a focus on transformation. The second gap needs to be addressed by work that focuses on the value of the program itself and the applied methods. Although already lots of research is present in the area of process optimization, further work with a focus on ET is necessary in that area. We further consider situational differentiation as appropriate, e.g. distinguishing complex service industries vs. volume operations, distinguishing different industries or further contextual factors.

\section{References}

1. Rouse, W.B.: A Theory of Enterprise Transformation. Systems Engineering 8:4, 279-295 (2005)

2. Moreton, R.: Transforming the organization: the contribution of the information systems function. Journal of Strategic Information Systems 4:2, 149-163 (1995)

3. Österle, H., Winter, R.: Business Engineering. Springer, Berlin, Heidelberg, New York (2003)

4. De Reyck, B., Grushka-Cockayne, Y., Lockett, M., Calderini, S.R., Moura, M.: The impact of project portfolio management on information technology projects. International Journal of Project Management 23:7, 524-537 (2005)

5. Henderson, J.C., Venkatraman, N.: Strategic Alignment: Leveraging Information Technology for Transforming Organizations. IBM Systems Journal 38:2/3, 472-484 (1999) 
6. Rouse, W.B., Baba, M.L.: Enterprise transformation. Communications of the ACM 49:7, 67-72 (2006)

7. Lahrmann, G., Winter, R., Uhl, A.: Transformation Management Survey - Current State of Development and Potential of Transformation Management in Practice. $360^{\circ}$ - The Business Transformation Journal:1, 29-37 (2011)

8. Purchase, V., Parry, G., Valerdi, R., Nightingale, D., Mills, J.: Enterprise Transformation: Why Are We Interested, What Is It, and What Are the Challenges? Journal of Enterprise Transformation 1:1, 14-33 (2011)

9. Ward, J., Uhl, A.: Success and Failure in Transformation - Lessons from 13 Case Studies. $360^{\circ}$ - The Business Transformation Journal:3, 30-38 (2012)

10. Robbins, S.P.: Organization Theory: Structure, Design, and Applications. PrenticeHall, Englewood Cliffs (1987)

11. Radeke, F.: Toward Understanding Enterprise Architecture Management's Role in Strategic Change: Antecedents, Processes, Outcomes. In: Wirtschaftinformatik Proceedings 2011. Paper 62. (2011)

12. Baumöl, U.: Strategic Agility through Situational Method Construction. In: Proceedings of the European Academy of Management Annual Conference 2005, München (2005)

13. Bucher, T., Klesse, M., Kurpjuweit, S., Winter, R.: Situational Method Engineering On the Differentiation of "Context" and "Project Type". In: Situational Method Engineering - Fundamentals and Experiences, pp. 33-48. Springer, Geneva (2007)

14. Yu, Z., Rouse, W.B., Serban, N.: A computational theory of enterprise transformation. Systems Engineering 14:4, 441-454 (2011)

15. Stiles, P., Uhl, A.: Meta Management: Connecting the Parts of Business Transformation. $360^{\circ}$ - The Business Transformation Journal:3, 24-29 (2012)

16. Moore, G.C., Benbasat, I.: Development of an Instrument to Measure the Perceptions of Adopting an Information Technology Innovation. Information Systems Research 2:3, 192-122 (1991)

17. Likert, R.: A Technique for the Measurement of Attitudes. Archives of Psychology 22:140, 1-55 (1932)

18. Flick, U.: An Introduction to Qualitative Research. Sage, London (2006)

19. Winter, R.: Organisational Design and Engineering - Proposal of a Conceptual Framework and Comparison of Business Engineering with other Approaches. International Journal of Organizational Design and Engineering 1:1\&2, 126-147 (2010)

20. Aier, S., Kurpjuweit, S., Saat, J., Winter, R.: Business Engineering Navigator - A "Business to IT" Approach to Enterprise Architecture Management. In: Bernard, S., Doucet, G., Gøtze, J., Saha, P. (eds.): Coherency Management - Architecting the Enterprise for Alignment, Agility, and Assurance, pp. 77-98. Author House, Bloomington (2009)

21. Baumöl, U.: Change Management in Organisationen: Situative Methodenkonstruktion für flexible Veränderungsprozesse. Gabler, Wiesbaden (2008)

22. Eisenhardt, K.M., Graebner, M.E.: Theory Building from Cases: Opportunities and Challenges. Academy of Management Journal 50:1, 25-32 (2007) 
23. Noy, C.: Sampling Knowledge: The Hermeneutics of Snowball Sampling in Qualitative Research. International Journal of Social Research Methodology 11:4, 327-344 (2007)

24. Thompson, B.: Exploratory and Confirmatory Factor Analysis: Understanding Concepts and Applications. American Psychological Association, Washington, DC (2004)

25. Gordon, A.D.: Hierarchical Classification. In: Arabie, P., Hubert, L.J., De Soete, G. (eds.): Clustering and Classification, pp. 65-121. World Scientific Publishing, River Edge, NJ (1996)

26. Neuendorf, K.A.: The content analysis guidebook. SAGE Publications, Thousand Oaks, CA (2002)

27. Härdle, W., Simar, L.: Applied Multivariate Statistical Analysis. Springer, Berlin, Heidelberg (2007) 